\title{
ACKNOWLEDGMENTS
}

This book was inspired by the interdisciplinary teaching and transnational approach of the faculty at the School of Architecture's History, Theory, and Criticism of Architecture and Art (HTC) program at the Massachusetts Institute of Technology (MIT), where I received my $\mathrm{PhD}$. My seven-year tenure there changed the way I look at the world. There, I learned that art and architecture are not impermeable, that is, they are not hermetically sealed aesthetic structures but rather porous inquiries into issues of power, inequality, and bigotryunderstood not as natural disasters that must be endured but rather as symptoms of deeply rooted structures that must be interrogated, challenged, and even changed.

At MIT, I must first acknowledge my dissertation committee: Arindam Dutta, who taught me what critical and innovative thinking really means; Mark Jarzombek, who expanded my way of thinking to a bigger arena; and Robin Greeley, who taught me to scrutinize the tiniest details of my writing and thinking and who challenged me to examine my own biases and sensitivities as a relatively privileged Latin American in a challenging global context. I owe an intellectual and personal debt to many other professors, colleagues, and staff at MIT. Among them, I would like to especially thank Caroline Jones, whose supportive close reading and always meaningful criticism was invaluable to me; my colleagues and friends Deborah Kully, Lydia Kallipoliti, Winnie Wong, Patrick Haughey, and Tali Hatuka, who at different stages of this work provided sustaining intellectual and 
emotional support; and Steve Strang and his extraordinary team at the MIT Writing Center, who taught me all I know about writing in English, especially Marilyn Levine, who accompanied me in this journey from its very first lines. I hope this book reflects the extraordinary input I received from all of them.

This book also benefited from another community, the History of Art Department at the University of California, Berkeley, where I was lucky enough to spend two amazing years as a Mellon postdoctoral fellow revising my dissertation into a book under the inspiration of its brilliant faculty, especially Darcy Grimaldo-Grigsby, T.J. Clark, and Todd Olson. I am also indebted to the astute students in my "Nature In-Vitro" seminar, who read and intelligently critiqued early versions of my chapters. In particular, I am thankful to Sarah Cowan, Elizabeth Smith, Lawrence Schear, Steven Bernard, and Katalina Gallo, whose inquiries made me rethink my work in an innovative way. This was one of the most memorable courses I have ever taught.

During the years of archival research and writing, this book took me to different countries, where I had the guidance and support of many colleagues, friends, librarians, and archivists: In France, I found inspiration and joy from my colleagues Jennifer Grotz, Barbara Diefendorf, and Karen King-Aribisala at the Camargo Fondation in Cassis; and from Felice Varini, Isabel Hérault, Yves Arnod, and Manuel Bello in Paris. In Brazil, Gisele Sanglard, Ana Luiza Nobre, Otavio Leonídio, Rosa Costa Ribeiro in Rio de Janeiro and Ana Maria Tavares, Roberta Saraiva, and Martin Grossmann in São Paulo offered invaluable resources and a remarkable sounding board for my ideas. In Argentina, Alicia Novick generously opened her personal archives for my examination, and Cécile Duret was my companion during my French readings and travels between Rio and Buenos Aires. I have also benefited from many archivists in these countries and the United States. I am particularly thankful to Cristina Zappa at the Instituto Moreira Salles and Michele Silva Moraes at the Academia Nacional de Medicina in Rio de Janeiro; and to the librarians at Widener Library, Houghton Library, Frances Loeb Library, and Countway Library of Medicine at Harvard University.

Throughout the making of this book, I received significant financial and institutional support from MIT; Harvard University; the University of California, Berkeley; Rice University; and other organizations. Early fellowships from MIT and Harvard, such as the MIT Royal Fund, the MIT Schlossman Research Award, MIT-France, and Harvard University's Center for European Studies Fellowship, funded the very first periods of research in Paris, where this story began. A CLIR 
Mellon Fellowship for Dissertation Research in Original Sources, the Charlotte W. Newcombe Doctoral Dissertation Fellowship from the Woodrow Wilson Foundation, the Dedalus Foundation Dissertation Fellowship, and fellowships from the Camargo Foundation and the Samuel H. Kress Foundation in the History of Art helped fund the research that later informed this book. More recently, the Mellon Postdoctoral Fellowship in the Humanities at the University of California, Berkeley, and a Humanities Research Center Faculty Fellowship at Rice University contributed to the process of refining my arguments and completing the manuscript.

The core ideas of this book were initially presented as talks, and the feedback obtained during these presentations was invaluable to the crafting of this book. I would like to especially thank: in France, the École Spéciale d'Architecture de Paris (ESA), the École Nationale Supérieure d'Architecture de Saint-Étienne, and the Camargo Fondation, Cassis; in Switzerland, the Swiss Federal Institute of Technology (ETH), Zürich, and Franklin College, Lugano; in Canada, the University of British Columbia, Vancouver; in Brazil, the Universidade de São Paulo and the Pontifícia Universidade Católica do Rio de Janeiro; in Venezuela, the Universidad Simón Bolívar, Caracas; and here in the United States, Harvard University; MIT; Savannah College of Art and Design; Vanderbilt University; Florida Atlantic University; Brandeis University; Syracuse University; University of California, Berkeley; University of California, San Diego; and Rice University. This study was also enriched by contributions from the audiences at academic conferences where I presented sections of this book, especially at the New England Society of Architectural Historians (NESAH), the Latin American Studies Association (LASA), and the European Association of Urban History (EAUH).

Rice University has been the perfect environment for me to write this book: incredibly stimulating, interdisciplinary, and intellectually challenging. Gordon Hughes, Luis Duno-Gottberg, and Gisela Heffes read sections and then offered brilliant insights. I gained new perspectives at regular meetings with colleagues at the Humanities Research Center during our year as fellows: from Alida Metcalf and Fares El-Dahdah, I developed a better understanding of the historical urban transformation of Rio de Janeiro; from Reto Geisser, Mariola Alvarez, Elizabeth Farfán Santos, Julie Fette, Sarah Stevens, Marcia Brennan, and Manuel Gutiérrez, I learned how to interrogate my own research from different angles. I am forever grateful to friends and colleagues at Rice University who generously gave their time and attention to me and my work, including Shirine Hamadeh, Graham 
Bader, Lida Oukaderova, John Hopkins, Lisa Balabanlilar, James Sidbury, Sarah Whiting, and Beatriz González-Stephan, and especially Linda Neagley for her unwavering support as department chair. Likewise, I owe many thanks to the undergraduate and graduate students in my seminars, who brought to my attention work that contributed to the improvement of this book, read draft chapters, and inspired me to revise them under a different light.

At Rice, my heartfelt gratitude goes to two $\mathrm{PhD}$ candidates in particular: Nikki Moore and Olivia Wolf. Nikki Moore has collaborated with me on countless projects, both at MIT, where she received her master's degree, and at Rice, where she was again both my student and, in another sense, my colleague. Like collaborating scientists, Nikki and I coauthored articles that drew from my work on eugenics and hers on sustainability, and my work on biopolitics and hers on agriculture. Through this partnership, I came to more fully value interdisciplinarity and intellectual dialogues. In her thoughtful reading of my manuscript, Nikki brought her political and social sensitivity to bear on her discussions with me, always deepening my investigations and analyses. And Olivia Wolf went beyond navigating archives in Buenos Aires, where she found missing plans and relevant documents, strengthening my understanding of early-twentieth-century Argentine literature and supporting me in the arduous job of building a bibliography and finding images and their copyrights.

Many different skills are needed to transform a manuscript into a book, and I would like to thank the editorial team at the University of Texas Press, in particular my editor Robert P. Devens, for his lively and early interest in my work, for his sensitive commentary, and for turning this arduous task into a real joy; Sarah McGavick, for her support throughout the process of revising texts and evaluating images; and Lynne Chapman and Nancy Warrington, for the meticulous process of copyediting this book. My gratitude also goes to Sophia Beal, whose insightful remarks on the porous frontiers between fiction and reality, and culture and science, in modern Brazil were simply invaluable, and to Christina Cogdell, whose expertise in the field and sharp criticism deeply enriched my book. Both reviews made my book much better. My thanks also go to Bruno Carvalho at Princeton University and Felipe Correa at Harvard Graduate School of Design, the coeditors of Lateral Exchanges: Architecture, Urban Development, and Transnational Practices, the new series that this book inaugurates, for their complicity and support during this process. I celebrate their initiative to make us rethink our preconceived maps of the world - the geopolitical hierarchies that omit influential 
regions such as Latin America from our understanding of the global project of modernity.

I would be remiss if I did not also thank Dianne Harris, dean of the College of Humanities at the University of Utah, and Abby Collier, editor in History and Philosophy of Science, Architecture/Built Environment at Pittsburgh University Press, whose interest in my work was a meaningful part of this process. I also extend my thanks to William Howze for his resourceful assistance finding copyrights and images for this book. I am particularly honored to have received the SAH/Mellon Author Award from the Society of Architectural Historians to help fund image licensing and reproduction costs.

On a personal note, I would like to thank a group of dear friends and family members who provided critical support at different stages of what has, at times, been a difficult process. I feel moved and proud to mention Mierta Capaul, Benjamín Caballero, Luis López-Durán, Alicia Molero, Phillipa McDonald, Gabriela Gamboa, Nancy Bulkeley, Tom Bulkeley, Susan Goldman, Manuel Delgado, Olivier Humbert, Lisette Avila, Juan Carlos López-Durán, Caroline Reeves, Ignacio Inglessis, Isabella Bulkeley, and María Inés Sicardi. I will never forget the generous support given to me by my youngest brother, Néstor López-Durán. I do not know the precise moment when he went from being my little brother to being my guide, the scholar and the person I am most proud of in the world. And finally, to the López-Durán clan, my family, my intimate circle of love and support: it has been a joy to have each of you feeling so close during the long making of this book.

This book would not have happened without:

my life partner, Carlos Pelayo Martínez, an endless source of love, friendship, and unconditional support. He inspires me every day with his intelligence and humor. He is, without a doubt, the main source of my joy, my beloved refuge, my resting place. Thank you for accepting this work as part of our life together.

and

my soul sister, Marilyn Levine, who will always remain my intellectual compass, the best interlocutor a researcher could have, a narrative voice I have internalized, and the best present this work brought to my life.

This accomplishment is as much theirs as it is mine. 
THIS PAGE INTENTIONALLY LEFT BLANK 


\section{EUGENICS IN THE GARDEN}




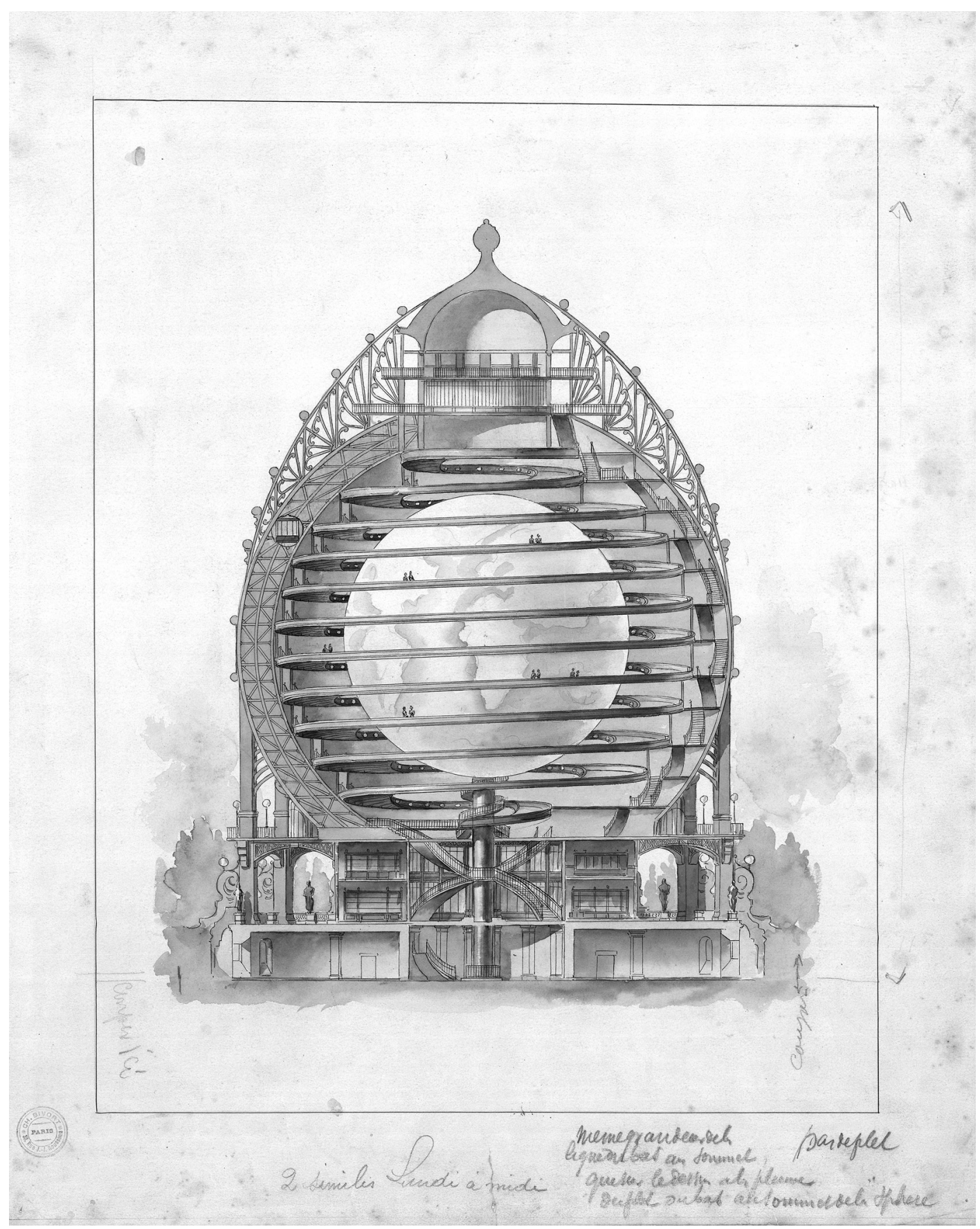

